\title{
ENERGY CONSIDERATIONS IN TANZANIA
}

By: A.A. Makange*

Introduction

Energy is vital in almost every aspect of man's existence on Earth whether it be energy to 'speak to others or energy to drive turbines in a power station.

Most industrial processes require that, energy be supplied in the form of heat or electrical energy. These forms are usually produced by conversion from another source - Chemical Energy. Materials which posses chemical energy are known as fuels. Those which occur naturally such as wood, peat, coal, crude petroleum and natural gas, are known as primary fuels. The term "fossil fuel", is used for coal and crude petroleum which were formed from organic matter many millions of years ago. Secondary fuels are produced from some naturally occuring material by a treatment process which alters the material chemically. Examples a re charcoal, town gas, motor gasoline and coke.

Since energy is so important to our present development it is necessary to be aware of the natural reserves of primary fuels. In view of the limitation of the worlds fuel reserves it is essential that fuel be more efficiently extracted from the earth and more efficiently utilized.

Wood and Charcoal

After serving as the main cooking and heating fuel for centuries, wood is being increasingly abandoned whenever oil, coal, gas and electricity become available. Up to date, out of the total consumption of wood (including over 800 specie mapped in Tanzania) more than $96 \%$ is used for charcoal and firewood.

\begin{tabular}{|c|c|c|c|c|}
\hline \multirow[t]{2}{*}{ Product } & \multicolumn{2}{|c|}{ Consumption } & \multicolumn{2}{|c|}{ Roundwood Equivalent } \\
\hline & Unit & Quantity & $m^{3}(r) \quad 100$ & $\%$ \\
\hline $\begin{array}{l}\text { Sawnwood } \\
\text { Plywood } \\
\text { Particle board } \\
\text { Fibreboard } \\
\text { Paper \& Paperboard } \\
\text { Poles } \\
\text { Charcoal } \\
\text { Firewood }\end{array}$ & $\begin{array}{l}\mathrm{m}_{3}^{3}(\mathrm{~s}) \\
\mathrm{m}_{3}^{3} \\
\mathrm{~m}^{3} \\
\text { tons } \\
\operatorname{tgns} \\
\mathrm{m}_{3}^{3}(\mathrm{r}) \\
\mathrm{m}_{3}^{3}(\mathrm{r}) \\
\mathrm{m}^{3}(\mathrm{r})\end{array}$ & $\begin{array}{r}162,400 \\
4,000 \\
1,620 \\
3,620 \\
22,620 \\
630,000 \\
820,000 \\
29,660,000\end{array}$ & $\begin{array}{r}406 \\
9 \\
2 \\
7 \\
113 \\
630 \\
820 \\
29,660\end{array}$ & $\begin{array}{c}1,3 \\
- \\
- \\
- \\
0,4 \\
2,0 \\
2,6 \\
93,7\end{array}$ \\
\hline Total & & & 31,647 & 100,0 \\
\hline
\end{tabular}

Table 1. Consumption of wood and wood-based material (1970) in Tanzania. The pattern of consumption is not considered to have changed much.

To consider using wood for fuel, it should be available at low cost in the immediate area and should, most importantly, be obtained by methods that do not ruin the environment. For the domestic use, as well as for industrial use (timber to be sawn and made into board products) therefore, the ideal source of firewood"

*Lecturer, Chemistry Department, University of Dar es Salaam, now pursuing. $\mathrm{Ph}$.D. studies in Chemical Engineering at the University of Trondheim, Noroway 
and charcoal is a managed woodlot. It has been observed that on a wide-spread basis, indiscriminate use of firewood can be disastrous. When much forested slopes of a country are stripped of their trees to provice firewood, charcoal and timber, erosion and general ecological havoc results.

The obvious useful values of a woodlot are for timber and fuel production; but even a small growth of trees can have considerable benefits as well. The soil can be restored on a land that has been ruined by erosion by planting trees at the affected area. Apart from controlling erosion and rejuvenating soil, trees can have some important influence on the climate of land by helping to mederate temperatures and humidity. In addition a woodlot provides food and shelter for wildlife. it he auuve benefit justifies the patience to manage a woodlot.

One of the advantages of using wood as fuel lies in the fact that wood-smoke contains almost no sulfur dioxide, in contrast with heating oil or coal which can give off large quantities of this dangerous gas. Further contrast to fossil fuels (coal and oil), wood is a revewable energy source that can to some degree continually replaced. With a little care wood can be obtained without much damage the environment, unlike the gougling, drilling and processing needed to obtain fossil fuels.

In towns as well as in rural areas, charccal has taken over the place of firewood. Although charcoal offers higher heat-value and is more convenience than plain wood, it is also relatively more expensive both in terms of labour and environmental disturbance. Large volumes of wood are needed, and the local method of preparing charcoal results in naked pits being left behind after removing the prepared charcoal. The cutting of large volumes of trees, leaves vast areas of bare land and coupled with the pits, these pieces of land become highly susceptible to wind and rain erosion, let alone pigration of wildlife. It should be remembered that the charcoal makers have to shift from one place to another in search of more wood, as one area after the other gets depleted of its trees.

A better practice in the production of firewood and charcoal should be furnished through plantations in connection with Ujamaa Villages. This consequently necessitates the design of simple and efficienti hearth or stove - a challenge to our local engineers.

Simple hearths would probably save a lot of wood as a result of efficient conversion of wood to charcoal, in addition to eliminating the empty, open pits. Efficient charcoal-stoves for domestic use will certainly save a tot of charcoal, and consequently wood, as well as add to comfort indoors. Charcoal is here to stay for at least the next ten years, and hence the need to control its production before the forests, are seriously affected. On the other hand, the present low cost of charcoal contributes to the misuse of this energy, especially in burning large amounts of charcoal even when very little amount of heat is required, in say boiling water for making tea. Also a lot of heat is wasted if the charcoal stove is not extinguished immediately after the cooking is over. The emphasis then should be on education and conservation.

Harvesting wood (trees) for firewood and charcoal making, as well as for timber, requires careful management on a sustained-yield basis allowing the user and nature, each year to grow back the amount of wood that has been removed. As afore said, this will be achieved through plantations, and to a lesser extent but equally effective, by individual initiatives towards forest preservation and efficient utilization of wood and charcoal as a fuel. On the other hand at least several hundreds of acres of sustained yield forest land are needed to supply firewood and charcoal for home use alone and complete relience of firewood and charcoal as our main source of energy is obviously not a realistic long term answer to even our present energy needs. 


\section{Electricity}

The present TANESCO production of $102 \mathrm{MW}$ of electricity ${ }^{3}$ together with the $600 \mathrm{MW}$ that will be obtained from the Stiegler's Gorge Hydroelectric Power Project ${ }^{4}$ when in operation (after 1980), should play an important role in providing energy for both domestic use and industries to be established. The present (1977) production capacity of electricity in Tanzania is illustrated in table 2 .

\begin{tabular}{lc}
\hline Mode of Production & $\begin{array}{c}\text { Amount } \\
\text { (MW) }\end{array}$ \\
\hline Hydro-electricity & 149 \\
Diesel-generated .... & 87 \\
Gas Turbine & 15 \\
\hline
\end{tabular}

Table 2. Electric Energy Production in Tanzania $(1977)^{3}$

The domestic use of electric energy may unfortunately depend on the opening up of new industries at various regions in the country, for it may be prohibitively expensive to electrify remote villages where no nearby industries exist. In addition, for people to use electricity for cooking purposes, cheap and easy electric cookers should be available. This may be possible if they are locally manufactured, especially when the metal industry in Tanzania is operational.

There is also an understandable temptation to use the Songo. Songo Gas resources as a source of fuel for domestic purposes. This demands massive introduction of gas cookers, which like electric cookers need to be locally manufactured, are less safe and quite inconvenient to use. It may bethore wise to save this non-renewable fuel for manufacture of other complex chemicals such as plastics, solvents and membranes etc.

\section{Coal}

Coal is clearly our most abundant domestic fossil fuel resources with identified reserves totalling well over 6,500 million tons ${ }^{5}$. In Tanzania coal is a combustible sedimentary rock occurring in workable quantities as distinct beds or seams. Tanzanian coals are similar to those of Southern Africa, India and Australia, by their petrographic and chemical constitution and physical characters. The coal fields in Tanzania known to be of economic and industrial value are Ruhuhu coalfields, Songwe-Kiwira coalfield, Galula coalfield, Ufipa, Mhukuru, Mbamba Bay, Njuga and Ilima coalfield, and these occur in Nyasa - Ufipa Rukwa zone. In rank, the coals are from medium to high volatile bituminous.

\begin{tabular}{|c|c|}
\hline 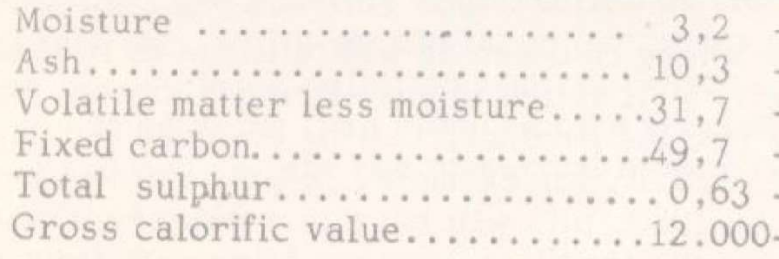 & $\begin{array}{l}-\quad 4,9 \% \\
-\quad 14,9 \% \\
-\quad 32,2 \% \\
-\quad 53,1 \% \\
-\quad 0,85 \% \\
-\quad 13.000 \mathrm{KJ} / \mathrm{Kg}\end{array}$ \\
\hline
\end{tabular}

Table 3: Sample analysis of Ilima Coal (Air dried basis) ${ }^{6}$

Surface layers of coal are strip-mined by using the techniques of area of contour mining. In the USA underground layers have been recovered by methods involving a room and pillar technique, whereas Longwall technique has been widely-in Europe. Still, improved mining technology is being developed? Lemployed 
Coal production Tanzania is probably done through the strip-mining technique, and hence the low cost of coal ( $\mathrm{a} \mathrm{kg}$ of bulky coal sales at $10 /-$ Tsh.) ${ }^{2}$. As the mining goes deeper and deeper the cost will get higher and higher. Among the limiting factors in the coal production will be, the availability of competent manpower (Engineers and related workers), adequate transportation systems, and new technology for better productivity.

Consideration of a number of geological, mining, geographical, economical and social factors are necessary in the assessment of the coal resources. So far, the coalfields are conveniently placed for a good market in Central and East Africa. Of those known coalfields in Tanzania, some are relatively small, but three of them promise to be extensive.

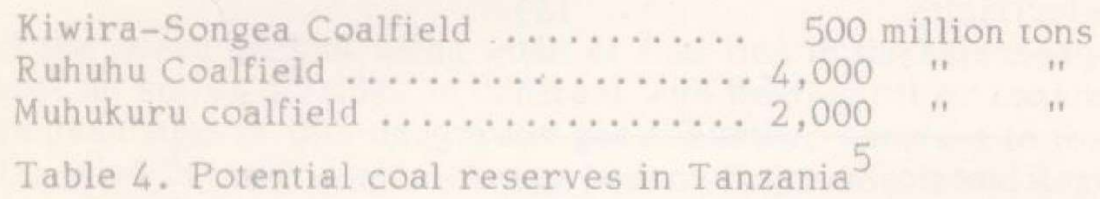

Only these three areas have potential reserves of 6,500 million tons of bituminous coals. It is possible that the figures given above, underate the total coal reserves.

Any strategy for reducing our long term dependence on imported energy must inculde the utilization of coal. The estimates of coal demand depend on projections of manufacturing growth, in industry - especially steel industry - and also on growth in demand of electricity - generation by coal.

The high calorific value of Tanzanian coal, $2,8.10^{4} \mathrm{KJ} / \mathrm{Kg}$, coupled with a low sulfur content of $0,7 \%$, renders it very suitable for industrial use and less so for domestic or home cooking purposes. It can be used for home-cooking provided appropriate stoves, that will facilitate efficient combustion so as to reduce formation of carbon monoxide gas, which is p'oisonous, and also to make maximum use of the energy in the coal. With the conventional charcoal stove, much heat will be wasted to the surroundings, and this will be a misuse of this valuable resource. Certainly stoves with chimneys will be necessary for disposal of the flue gases out of the house.

One should not be tempted to putting coal into domestic use on the assumption that, if it has been used in India, then it can be used in Tanzania. Had it been exactly the uame type of coal and under the same conditions of use the statement would have been valid, but coal composition depends very much on its place of origin. It would be more constructive for those concerned with exploiting and marketing coal to carry out elaborate scientific assessment of the health - hazards associated with burning coal. The information thus obtained should then be made public knowledge.

The most appropriate area where coal can be well utilized is in industry. ement processes are particularly well suited to coal-firing because, most of the fuels sulfur and ash go directly into the product, cutting the need for expensive waste-disposal systems. In the U.S.A. for example, $76 \%$ of the total number of cement kilns are coal fired and by 1980 , this will have increased to $90 \%$. One much advocated possibility is to replace the traditional rotary kilns with fluidized-bed type units. Designers of this process claim that it has the advantage of sending volatiles and ash to the flue via indirect heat exchanger $g$ thus obviating the chance of plugging in the conventional kilns pre-heaters

In developing countries, Tanzania in particular, the change of existing kilns design may be unnecessary in the immediate future - since there is only one cement factory - (Tanzania Portland Cement Factory at Wazo Hill). - However, the plans 
to build new Cement factories should probably take into account the fact that coal is abudant in Tanzania and the world as a whole. Tanzania, like most developing countries, do not manufacture machines as such (due to lack of Steel Ind istry and necessary technology), therefore relies on ready made machine equipments from abroad. Therefore those people with the task of ordering equipments or complete industries have a national responsibility always to take into account our unique local conditions and the ever changing world technology. They should always consider the possibility of designing new plant s with coal-fired units, especially steam-boilers, furnaces and cement-kilns and whenever possible avoid buying complete design, ready made processes and equipment s. However, this requires a special brand of local enginȩers who are well equipped with plant design and process engineering knowledge follows:

Coal, like oil, may be used in electrical energy production, as

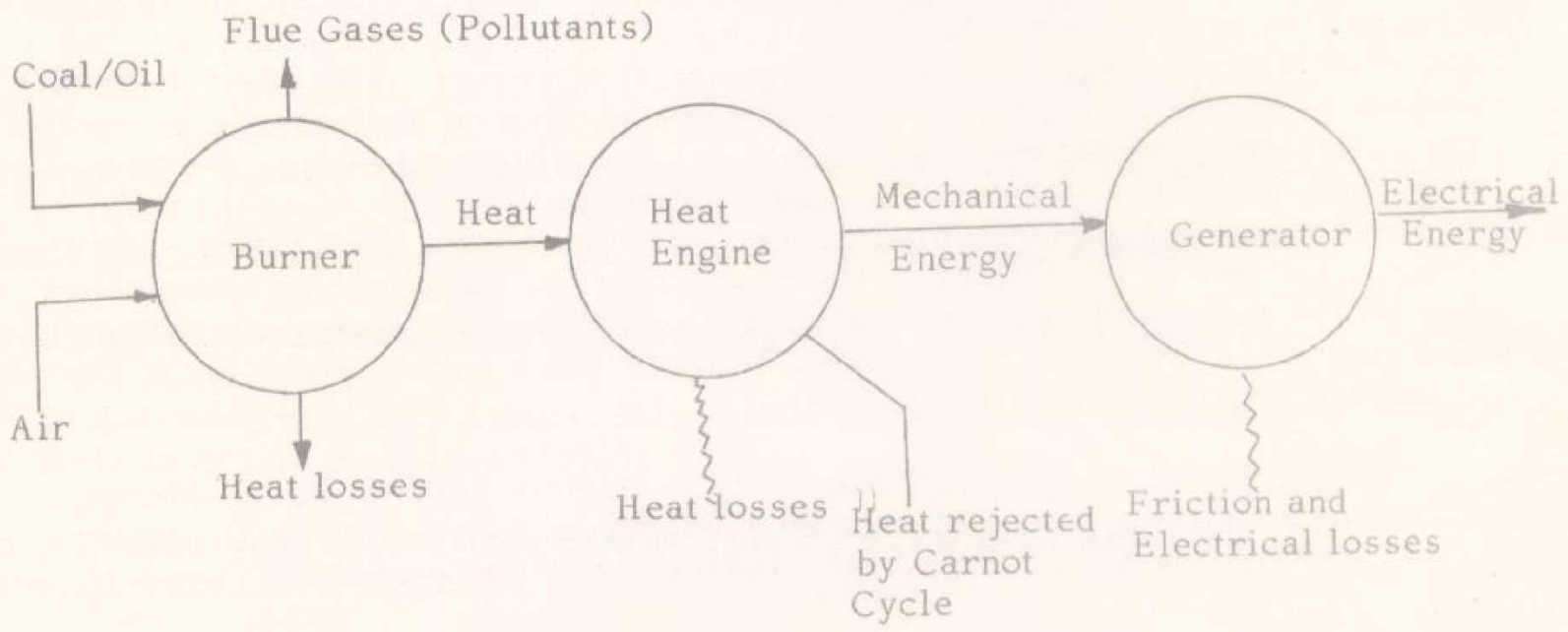

Fig. 1: Stages involved in electrical energy production by fuel burning.

The burning of the fuel, gives Carbon dioxide, water vapour and heat. The heat is used to produce steam at high pressure, in a steam-boiler, and the steam then expanded to move a steam-turbine. The mechanical energy thus produced in the steam-turbine is used in generator to produce electrical energy.

The pollutants produced in the burner include: Carbon Monoxide, Sulfur dioxide, oxides of nitrogen $\left(\mathrm{NO}_{\chi}\right)$, particulates, possible trace elements and polycyclics.

The industrial use of coal will require serious considerations regarding transportation, and possibly construction of slurry pipe lines. $\cdot$ Coal burning power plants etc. will also add large quantities of environmental pollutants and therefore necessitates pollution control devices. Sulphur dioxide thus produced may be scrubbed using lime stone to give Gypsum, which may be used in manufacture of wall-board and cement and numerous other products The coal ach may ind foreign markets

espite un mese opportunities for utilization of the flue gas cleaning wastes, disposal of these processed wastes will be practiced and therefore remain a problem. In the industrialized countries, USA in particular, several xganizations are already working to overcome this problem

In this country as in any other, a complete switch from oil or gas is not feasible, maybe, the half way measure of blending one type of fuel with another including coal, may help. Some Tanzania bituminous coals has a volatile content around. $32 \%$ and therefore suitable for liquid fuels synthesis and for extensive chemical industry. 
The reaction of coal with air-steam or oxygen-steam mixtures can be used to produce a low $(2800-5600)$ or intermediate $(5600-11000) \mathrm{kJ} / \mathrm{m}^{3}$ fuel or synthesis gas containing $\mathrm{CO}$ and $\mathrm{H}_{2}$. Either of these products suitably cleaned can be used for fuel gas in industrial utifity applications. This process is known as coal - Gasification. Gasification can be accomplished in fixed-bed, fluidized, entrained or molten-bath reactors.

Carbonization of coal may be performed to give coke. Hard coke is produced from coals yielding between 18 and $32 \%$ volatile matter and it finds use in blast-furnaces in metallurgical processes, Coals of lower rank, yielding up to $40 \%$ volatile matter, are used in carbonization either alone or in blends to give coke suitable for domestic use. The coke in this case is relatively smoke free.

\section{Solar Energy}

Utilization of solar energy is another very important field of "applied research". Tanzania is abundantly endowed with this source $\beta^{f}$ energy ${ }_{7}$ The amount of solar energy falling on the earth's surface is $4.6 \times 10^{20} \mathrm{~kJ} /$ year ${ }^{7}$, or well over $1 \mathrm{~kW} / \mathrm{m}^{2}$ of which a large portion is in equatorial countries. The present world research is geared towards producing economical efficient and socially acceptable solar collectors. So far the direct use of solar-energy for heating, has been judged to be most attractive and it is under intensive development-world wide. The present cost for photovoltaic converters is more than a few hundred. shilling per watt, and this is too high by at least two orders of magnitude for competitive solar-power utilization in central power stations. Thermal energy conversion in steam engines is limited by the Carnot Efficiency which equals a fraction of a percent for temperature differences up to about $10^{\circ}$

Concentrated research in this field is certainly worth while considering the amount of sunshine period in Tanzania. Some work on Solar water heating systems has already been started at the University of Dar es Salaam 4.

\section{Conclusion}

Use of charcoal - stoves in the rural areas in Tanzania should not be discouraged. However, the practice of digging big holes into the ground for charcoal manufacture should be discouraged because of the resulting ravaged land, which consequently undergoes soil erosion. Appropriate kilns should be constructed at say co-operatively in a village, and the charcoal preparation should be centrally controlled. This control should be such that the felling of trees is controlled, and trees are replanted from time to time to render charcoal a renewable fuel, in practice.

Where electricity is available it should be employed for domestic use. There is however a need for the manufacture of low-cost electric plates for cooking. This should pose a challenge to our local enginerrs.

The use of coal should be taken with caution. A way to deviate the hazardous flue-gas from the room to the out side need be considered. In addition the existing charcoal-stoves need re-designing for efficient coal-combustion so as to minimize waste heat to the surrounding (the room), where house warming is not required and minimize the emission of harmful gases. Coal-gasification processes need be considered and its economic feasibility studied.

Future technology, which is still under fabrication, will provide us with cheap and efficient means of converting coal to liquid fuel and use in extensive chemical industry. The concern should not be with the amount of our natural gas or coal resources, but rather with developing the technology that will allow them to be efficiently converted into energy and processed into materials at acceptable costs and with a minimum of waste and environment degradation. The energy problem may not be so urgent now but we should be planning and experimenting now to make sure that there is sufficient energy available in the future to avoid possible dependence on fuel imports and maintain our changing life style. 
An important consideration in reducing demand is to eliminate fragrant waste, such as unnecessary use of lights or other equipment, and minimizing auto trips to the corner grocery. This paper is presented not only ita: gear renewable energy systems to meet our future high demands, but also, to conserve what we already have. It is intended to open way for discussion among scientist and the laymen at large, concerning our past present and future use of the various forms of energy.

Scientists should be more concerned about the society around: them, and whenever possible they should be prepared to provide the public with some scientific knowledge, so that they can help society realize its combined environmental, social and economic goals. In all then scientists need to participate; and at a large measure, in the decision-making processes that affect the nation's quality of life.

\section{References}

1. Nils Lundborg, Fuel from Wood (1977), Private Communication.

2. Daily News (Tanzania), 14/1/1977, -STAMICO to set up coal centres.

3. TANESCO, A Report on Maximum Demands for 1976, Private Communications .

4. Daily News (Tanzania), 26/1/1977,-- Norway to aid Power Project.

5. P. Bomboe, Lectures on Fuels, University of Dar es Salaam (1974).

6. N.G. Mahinda, Fuel Unit Report, Nos, 7-10, Department of Chemistry University of Dar es Salaam (1973).

7. S.S. Penner and L. Icerman, Energy Vol.11, Addison-Wesley Publ. Co. Inc., London (1975) Page 71.

8. J.W. Jones, Chem.Eng., Vol. 84, No. 4, (1977).

9. A.A. Makange et.al., Preliminary Process Design Development and Economics for Purification and Utilization of Waste Gypsum . M.Sc. thesis, NTH (1977).

10. J. Audo, Chuo University, Tokyo, Status of Flue ‘Gas Desulfurization and simultaneous removal of $\mathrm{SO}_{2}$ and $\mathrm{NO}_{y}$ in Japan. Presented at 6 th EPA Symposium on Flue Gas Desulfurization., New Orlens, March 1976.

11. J.K. Dent., Central Electric Generating Board (CEGB) London, U.K., "England Over View" presented at 4th International Ash Utilization Symposium, St. Louis (1976).

12. M.F. Granville, Engineering, Science and the Energy Supply Challenge. Ind. Eng. Chem. Fundam., Vol. 16, No. 1, (1977).

13. A.A. Makange, Industry and Development, UHANDISI Journal, Vol.4, No.1, (1978).

14, R. Reichel, UHANDISI Journal, Vol. 3, No. 1, (1976). 


\section{BOOKS FROM LONGMAM}

ELBS: ENGINEERING SCIENCE IN S.I. UNITS

Shs. 43.00

E. Hughes

This volume covers the subject matter in Engineering Science of the G1 and G2 General Course in Engineering

ELBS: ELECTRICAL TECHNOLOGY S.I. UNITS

Shs. 42.75

E. Hughes

Now available in S.I. Units, the section on Electronics and

Semiconductor Devices have been updated and adapted to the

first year syllabuses of degree and diploma courses.

ELBS: ELECTRICAL INSTALLATION WORK S.I. UNITS

Shs. 22.00

The contents include: Supply Systems, Consumer Circuits,

Conductors and Cables, Testing Instruments and Measurements,

Telephones, Questions and Answers.

ELBS: INTRODUCTION TO THE MECHANICS OF MACHINES

J.L. Morrison

For students wonking on diploma and degree courses

BASIC MECHANICAL ENGINEERING

Shs. 66.50

R.L. Timings

It covers the option in the first year of Engineering Craft course syllabus

\section{LOMGMAN TAMZAHIA LIMITED}

P.O. BOX 3164, DAR ES SALAAM. 